\title{
Nataša Puškar, Srpski bukvari 1965. - 2011. Socijalno-semiotička analiza. Zagreb: SKD »Prosvjeta«, 2021. - 204. str.
}

Monografija Srpski bukvari 1965. - 2011. autorice Nataše Puškar objavljena je 2021. godine u izdanju Srpskoga kulturnog društva »Prosvjeta«. Riječ je o studiji posvećenoj socijalno-semiotičkoj analizi slikovnih i tekstualnih sadržaja bukvarā - početnica namijenjenih usvajanju pisma u nižim razredima osnovne škole - koji su bili u upotrebi u srpskim školama u drugoj polovici 20. te početkom 21. stoljeća. Budući da ova vrsta nastavnoga pomagala za mnoge predstavlja mjesto prvog izravnijeg susreta s pismom, utjecaj bukvara na djecu neupitan je, što predmet ovog istraživanja čini društveno relevantnim i aktualnim. Autorica se u knjizi fokusirala na sredstva i načine reprezentacije koncepata etniciteta i domovine te rodnih odnosa u bukvarima, nastojeći odgovoriti na pitanje kako su se društveno-političke promjene iz druge polovice 20. i s početka 21. stoljeća odrazile na planu njihovih slikovnih i tekstualnih sadržaja.

Ova knjiga prerađeno je i prošireno izdanje autoričine doktorske disertacije koju je napisala i obranila 2020. godine u sklopu Poslijediplomskog doktorskog studija lingvistike na Filozofskom fakultetu Sveučilišta u Zagrebu pod mentorskim vodstvom prof. dr. sc. Mislave Bertoše i prof. dr. sc. Milorada Pupovca.

Knjiga je organizirana u šest cjelina. U prvoj cjelini knjige doznajemo što su to bukvari, koja su glavna obilježja ove vrste nastavnog pomagala, kako je tekao njihov razvoj kroz povijest te koji su najznačajniji srpski bukvari od početka njihova objavljivanja krajem 16. stoljeća do vremena objavljivanja bukvara obuhvaćenih analizom predstavljenom u ovoj knjizi. Riječ je, naime, o trima bukvarima objavljenim u drugoj polovici 20. stoljeća (1965., 1974. i 1996. godine) te jednome bukvaru iz 2011. godine.

Druga cjelina knjiga posvećena je prikazu društveno-povijesnih prilika koje su u razdoblju između 1965. i 2011. godine izravno utjecale na sadržaj analiziranih bukvara. U njoj nalazimo poglavlja posvećena prikazima nastanka SFRJ-a i poslijeratne obnove; razvoja industrije i procesa urbanizacije; kratke povijesti pionira; figure Josipa Broza Tita; buđenja vjerskih zajednica; raspada SFRJ-a i razdoblja tranzicije te društvenog položaja žena. Osim toga, ova cjelina knjige uključuje i poglavlja o Svetom Savi i Vuku Stefanoviću Karadžiću koji su također obuhvaćeni analizom bukvara kao važni motivi njihovih slikovnih i tekstualnih sadržaja.

U trećoj cjelini knjige autorica nudi sustavan i jezgrovit prikaz teorijskog okvira provedenog istraživanja. Cjelina se sastoji od dvaju poglavlja. Prvo poglavlje posvećeno je prikazu socijalno-semiotičkog pojmovnoga aparata te teorijsko-metodo- 
loških postavki provedene analize slikovnih sadržaja bukvarā koji se zasnivaju na Kressovoj i Van Leeuwenovoj teoriji socijalne semiotike iz 2006. godine. U drugom su poglavlju predstavljene teorijsko-metodološke postavke provedene analize tekstualnih sadržaja bukvara, utemeljene na Van Leeuwenovoj teoriji društvenih aktera i društvene aktivnosti iz 2008. godine. Autorica je navedene teorijske okvire prilagodila potrebama provođenja socijalno-semiotičke analize bukvarā, ponudivši prikladan model za njihovo tumačenje.

Četvrta cjelina, koja predstavlja središnji dio knjige, posvećena je dvjema analizama bukvarā, koje su predstavljene u zasebnim poglavljima. U oba je slučaja analiza provedena zasebno, nad pojedinim bukvarima (od najstarijeg prema najnovijem), a potom su njihova obilježja podvrgnuta usporedbi s ciljem utvrđivanja promjena koje su nastupale pod utjecajem izmijenjenih društveno-političkih okolnosti. Prvo poglavlje, naslovljeno Etnicitet, posvećeno je socijalno-semiotičkoj analizi reprezentacije fenomenā etniciteta i domovine, koji su - kako je pokazalo provedeno istraživanje - u bukvarima prikazani prvenstveno posredstvom pojedinih povijesnih ličnosti, državnih simbola te državnih institucija. Zbog toga su upravo ti motivi bili u najužem fokusu istraživanja. Drugo poglavlje, naslovljeno Rodni i međugeneracijski odnosi, uključuje analizu reprezentacije rodnih i međugeneracijskih odnosa u bukvarima - promatranih prvenstveno u kontekstu obiteljskih relacija. Pritom je posebna pažnja usmjerena na rodne stereotipe, koji su - zaključuje autorica knjige - u svim analiziranim bukvarima zastupljeni u većoj ili manjoj mjeri.

U petom poglavlju knjige ponuđena je sinteza rezultata i zaključaka proizašlih iz provedenog istraživanja. Jedan od ključnih zaključaka taj je da se neke društveno-političke promjene u bukvarima odražavaju vrlo brzo (npr. promjene društvenog uređenja), a neke izrazito sporo - npr. društvene promjene vezane uz rodne uloge i odnose. Kao primjer slikovnih i tekstualnih sadržaja podložnih brzim promjenama ističu se simboli državnosti i povijesne ličnosti, za koje je utvrđeno da su se $u$ analiziranim bukvarima smjenjivali usporedno s promjenama državnog uređenja. Tako primjerice lik Josipa Broza Tita - koji je predstavlja jedan od centralnih motiva u bukvarima iz druge polovice 20. stoljeća - uslijed raspada SFRJ-a biva zamijenjen likovima Svetoga Save i Vuka Stefanovića Karadžića u bukvaru iz 2011. godine. S druge strane, istraživanje je pokazalo da su prikazi rodnih uloga i odnosa u bukvarima prilično »otporni« na društvene promjene te da u pravilu ne idu u korak s promjenama položaja i prava žena koje su nastupile u posljednjih pola stoljeća. Primjerice, u svim četirima analiziranim bukvarima djevojčice i žene prikazane su kao pasivniji likovi od dječaka i muškaraca. Nadalje, prikazi djevojčica i odraslih žena pokazali su se stereotipnima na više razina - npr. na planu njihova fizičkog izgleda (npr. na slikovnim prikazima u pravilu djevojčice i žene imaju dugu kosu, nose suknju ili haljinu) i rodnih uloga (npr. odrasle žene najčešće su prikazane u ulozi domaćice i njegovateljice, a djevojčice ih oponašaju u tim ulogama).

Iako je istraživanjem utvrđen svojevrsni napredak na planu suzbijanja rodnih stereotipa i rodne nejednakosti u slikovnim i tekstualnim sadržajima bukvara, au- 
torica studije zaključuje da su oni i dalje prisutni. Upravo iz toga razloga autorica u posljednjoj cjelini knjige donosi preporuke namijenjene autorima budućih bukvara, utemeljene na rezultatima provedenog istraživanja. Time ova studija zadobiva iznimno vrijednu praktičnu dimenziju.

Monografija Srpski bukvari 1965. - 2011. Socijalno-semiotička analiza Nataše Puškar predstavlja vrijedan znanstveni doprinos na više razina. Osim što je u njoj predstavljeno prvo istraživanje u kojemu se bukvarima pristupa iz perspektive socijalne semiotike, ona predstavlja značajan doprinos razvoju ove discipline u hrvatskoj znanosti predstavljajući njezine temeljne postavke te demonstrirajući njezine mogućnosti i domete. Pored toga, ova će studija bez sumnje doprinijeti razvoju kvalitetnijih udžbenika i drugih nastavnih pomagala. U konačnici, ne sumnjamo da će se ova knjiga pokazati zanimljivim i korisnim štivom ne samo filolozima i pedagozima, već i stručnjacima iz područja drugih društvenih i humanističkih znanosti poput primjerice povijesti, etnologije i kulturologije.

Virna Karlić 